\title{
DRIVING FACTORS OF GROWTH EVIDENCE IN THE FOOD AND TEXTILE SECTORS OF PAKISTAN
}

\author{
ZAHID BASHIR ${ }^{1}$, MUHAMmad USMAN ARShAD ${ }^{2}$, MUHAMMAD ASIF $^{3}$, NUSRAT Khalid ${ }^{4}$
}

Abstract

\begin{abstract}
The aim of this research was determining the factors of growth in the textile and food sector of Pakistan. The research study analyzed data from the financial statements of textile and food sector companies of Pakistan for the period 2013-17. A fixed effect regression model was used for regression analysis after the conformation of (Hausman, 1970) specification test. The results of the study indicated that there was a significant and positive impact of profitability and negative impact of leverage on firm growth in textiles as well as the food sector of Pakistan. The results also indicated that firm growth was not significantly affected by innovation, liquidity or solvency. Growth of assets was used to measure firm growth. The findings of the study are applicable to textile as well as food sector companies in Pakistan. This research study suggested that management and policymakers in the textile as well as in the food sector of Pakistan should consider profitability as a driving factor for enhancing growth in both sectors. A small number of research studies could be found for the driving factors of growth especially in the textile as well as for the food sector of Pakistan. The present research study contributed to the existing literature by providing fresh evidence from Pakistan as a developing market. It allows the research community to explore the differences and similarities for the driving factors of growth in both sectors of Pakistan.
\end{abstract}

${ }^{1}$ Lecturer at Department of Commerce, University of Gujrat, Pakistan, e-mail: zahid.bashir@uog.edu.pk, ORCID: https://orcid.org/0000-0001-55461099.

${ }^{2}$ Lecturer at Department of Commerce, University of Gujrat, Pakistan, e-mail:usman.arshad@uog.edu.pk, ORCID: https://orcid.org/0000-0002-95315421.

${ }^{3}$ Lecturer at Department of Commerce, University of Gujrat, Pakistan, e-mail: asif@uog.edu.pk, ORCID: https://orcid.org/0000-0002-3338-1706. ${ }^{4}$ M.Com Student at Department of Commerce, University of Gujrat, Pakistan, e-mail:nusratmimi1022@gmail.com, ORCID: https://orcid.org/00000002-9462-9939. 


\section{INTRODUCTION}

Firm growth means the extension of a firm's size over time. The growth may be either internal or external. Some firms expand, remaining in their original lines and others may expand their activities through diversification. Industrial and individual's economic growth leads to the robustness of a society. The economies of the developing world create new employment opportunities through the formation and development of firms which enhance the potential for success. Economists, politicians and international development agencies have given extensive resources by recognizing the importance of the growth of firms through the execution and creation of programs that enhance economic prosperity and the growth of firms. Several authors have studied firm growth in different models. Churchill and Lewis(1983) developed the common growth model considering that a new company is in the stage of survival. Even though it is a fact that there will not be rapid growth in the industry. However, in the near future, the participating aspect of growth may prove its effect. That's why the participating aspect of growth is crucial for a young company for its long-time existence in the industry. According to the common growth model, as discussed above, the new companies are incompetent, less organized and less experienced. On the other hand, larger companies have adequate experience with more efficiency. There have been a few development theoretical frameworks about the creation and growth of firms and few of them have been tried widely as discussed by Davidsson et al. (2010) and Gibrat (1931). The law is perhaps the utmost recognized and practically tried theory for firm growth. The law hypothesizes that a firm's size is the result of a sequence of casual growth rates in the firm's history. Theoretically as well as empirically, a comprehensive analysis of other determining factors for the growth of the firms are less common. They considered both financial resources and technology collectively and, in previous works they were considered separately. They focused on developing or emerging economies. They found that the firm's growth in any time duration is not dependent on the firm's size at the earliest stage. The population for this study is the food processing companies relating to the food sector and textile mills from the textile sector of Pakistan for the period 2013 to 2017. The food industry is one of the major industries of Pakistan. Current GDP growth rate is $4.71 \%$ and the sector contributes about twenty-three percent in GDP and employs about forty-four percent in employability of labour force and about $65 \%$ to total exports of Pakistan. The Pakistan textile sector is the top-ranked segment around the globe. The segment of textiles in Pakistan has an irresistible influence on the economy contributing 52\% to the trade of the state. The textile objects of Pakistan because of their top value are distinguished around the world. Pakistan is the 2nd most inhabited country in the Muslim world and 6thin the world, according to (FAO) the food and Agriculture Organization of the United States. The Agriculture/Food sector of Pakistan is still playing a fundamental role in order to withstand such a massive population. Luckily Pakistan is the largest cultivator of wheat and has no need to import. Therefore, this sector is carrying out a twofold task for the development of Pakistan by providing food for such a massive population and facilitating economic growth through declining food imports. At this time Pakistan is producing about $10 \%$ of the global crop of cotton. The Pakistan textile sector imparts 8.5 per cent to Gross Domestic Product. About 40 per cent of the workforce is engaged in this sector. The purpose of the study is to observe the specific economic factors affecting the growth of food processing companies and textile mills in Pakistan for the period 2013 to 2017. Therefore, this study is based on the question of which specific factors influenced firm growth in the food and textile sector of Pakistan. The findings of the current study contribute by supporting managers in focusing efforts on the specific aspects formulating growth of the firms, and for the politicians and economists in planning the policies and achievement of business growth goals. Previous studies have been conducted using profitability, market beta or other factors affecting firm growth of Belgian companies, Italian small and medium-sized companies and emerging economies of Argentina, with the duration 2011-2014,1990-1999,2001-2006,1989-1997,1993-1994 respectively, while the current study is based on growth of the food processing companies and textile mills of Pakistan for the period 2013 to 2017.

\section{LITERATURE REVIEW}

This section contains the theoretical background to examine the determinants of firm growth. Leonardo et al. (2001) focused on the factors affecting the growth of SMEs and the importance of finance available through external sources. They used cross-sectional data of 
4000 Italian SMEs for the duration between 1989 and 1997. They analyzed the data by using the multivariate model. Independent variables of this study were size, age, leverage, exports and rent. Their findings were that finance is not neutral in small firms. Francisco et al. (2007) examined the factors involved in the growth of firms, and for this purpose data of Argentina SMEs from 1993-1994 was used. The data was analyzed by using ordinary least square and multivariate approaches. The purpose of this research was to examine the growth of firms in developing countries. Findings of this research showed that to deliver ample profits in an economy the government should introduce programs that focus on investigating the latest technology and moving from national to international trade for diversification. They used return on sales, size, mixed financial resources, technological level in industry, diversification involved in sales at domestic and international markets as independent variables. Teng and Arslan (2012) examined the determinants of firm growth and evidence for this purpose was taken from Belgium SMEs for the period 2001 to 2006. They used ordinary least square technique for testing. The objective of this study was to observe the financial components that explain the growth of firms in the Belgium context. Classical Ricardian, Managerial growth, peaking order and theory of constraint were the base theories for this study. Growth of the firm is dependent and leverage, profitability, solvency and innovation are used as independent variables. Tobias and Soenke (2014) examined the components of market beta which take the impacts of market condition and firm accounting figures. They used cross-sectional data for the period (1990 to 1999) using CAPM theory and OLS technique for testing. Beta was the dependent variable and growth, spread, income and productivity risk. They concluded that these key accounting figures play an important role as a component of market beta. Pierpaolo et al. (2014) extended the literature by observing factors of profitability in the EU-15 area, using panel data of 30,764 private firms for the period of 2004-2011. They used pooled ordinary least square for testing. The purpose of this study was to extend the literature by permitting for nonlinear effects of micro-level variables relating to micro and macro-level variables along with the determinants of profitability. They used return on assets as dependent variables; independent variables included typical micro level, additional micro and macro-level variables. Their conclusion highlights the effects of additional micro and macro-level variables on the profitability of the firm.
Rahmanet al. (2009) examined the association between economic growth and its factors taken by the development of the stock market in Pakistan. They used ordinary least square for testing by picking data during the period of 1971 to 2006. Their conclusions recommended a positive and significant relationship between stock market efficiency and economic growth.

\section{DATA \& METHODOLOGY}

\section{DAta \& ITS SOURCE}

Panel type data was used for this study. Financial statements of the food and textile sector of Pakistan were used for the collection of data that were available at company websites for the period 2013 to 2017. The food sector of Pakistan consists of 16 non-financial companies and the textile sector of Pakistan consists of 152 companies. It is considered a short panel as the period of study is short as compared to data of firms. The findings of this study are generally applicable to non-financial sectors and particularly to the food and textile sectors of Pakistan as the financial pattern of financial companies is different, so it is not applicable to the financial sector. Techniques applied for this study are correlation analysis and regression analysis and descriptive statistics.

\section{MODELLING OF THE STUDY}

The economic relationship between firm growth and its determining factors is as follows:

This relationship is stated as:

Growth $=f$ (profitability, leverage, innovation, liquidity, solvency)

The focus will be on the financial ratios for calculating firm growth. The theoretical explanation for the above association can be drawn by capital structure theories.

Based on the above economic relationship, the following econometric model can be established because the type of data is panel:

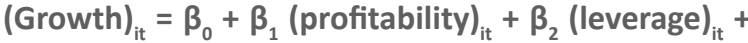
$\boldsymbol{\beta}_{3}$ (innovation) $_{\mathrm{it}}+\boldsymbol{\beta}_{4}$ (liquidity) $_{\mathrm{it}}+\boldsymbol{\beta}_{5}$ (solvency $_{\mathrm{it}}+\mathrm{U}_{\mathrm{it}}$

Growth of the firm is the dependent variable for the current study and the data for this purpose is from 2013 to 2017 and is expressed as percentage. There are five independent variables used to calculate the dependent variable. Those are profitability, leverage, innovation, 
liquidity and solvency ratios. The purpose of this study is to examine the relationship between growth rate and its determining factors using regression analysis. Uit is the representation of the error term in the panel data model of this study.

\section{VARIABLES' EXPLANATION}

The following variables were used in the current study.

\section{GROWTH OF THE FIRM}

Growth of the firm is the ratio between the growth rate average to total assets for the period from 2013 to 2017. As the growth rate can fluctuate from one year to another average growth rate is used for this study. This variable is used by Teng and Arslan (2012) as the dependent variable.

\section{Ratio of Profitability}

The first independent variable of this study is profitability which is measured by taking an average return on assets (Total assets/ shareholder equity) and data was used over the period 2013 to 2017. Glancey (1998) found that there is a positive and significant association between the profitability and growth factor of firms. According to Goddard et al. (2004), firm growth and profitability are not essentially associated with each other. Teng and Arslan, (2012) conclude that there is no significant impact of profitability on firm growth.

\section{RATIO OF LEVERAgE}

The second independent variable of this study is leverage. It is calculated through a ratio of liabilities to equity ratio from 2013 to 2017 . It is calculated by dividing liabilities and shareholder's equity. Teng and Arslan (2012) conclude that there is no significant effect of leverage on growth of a firm but there is a positive and significant relationship between leverage and growth of a firm according to the finding of Heshmati (2010) and Honjo and Harada (2006).

\section{RATIO OF INNOVATION}

The third independent variable is innovation. It is defined as the intangible asset ratio which is the ratio between intangible assets to total assets. According to Cainelli and Savona (2005) there is a positive relationship between the ratio of innovation and growth of the firm. LeBaset al. (2011) found that firms have more growth which innovate than firms that don't.

\section{RATIO OF LIQUIDITY}

The fourth independent variable is liquidity. For this study, it is defined as the ratio between current assets and current liabilities. Teng and Arslan (2012) found an insignificant relation of the ratio of liquidity and growth of the firm. Gill and Mathur (2011) expect that firms that have higher liquidity levels have less strict financing limitations. Anderson (2002) found a positive relationship for the ratio of liquidity and growth of the firm.

\section{Ratio OF SOLvency}

The fifth independent variable is solvency. This variable is measured by dividing shareholder equity by total assets for the period 2013 to 2017. Durinck et al. (1997) concluded a negative relation for the ratio of solvency and growth of the firm.

\section{Hypotheses}

The following hypothesis based on previous studies.

Table 1: Variable Measures and Expected Signs

\begin{tabular}{|c|c|c|c|}
\hline Sr\#. & Variables & Measures & Expected signs \\
\hline Dependent & Growth (GR) & $\begin{array}{c}\text { Change in total assets /total } \\
\text { assets }\end{array}$ & \\
\hline \multirow{5}{*}{ 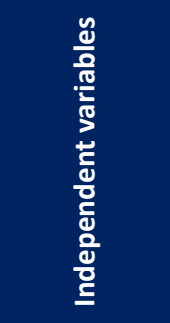 } & Profitability (PRF) & Net profit/shareholder equity & + \\
\hline & Leverage (LEV) & Total debt/total assets & - \\
\hline & Innovation (INV) & Intangible assets /total assets & + \\
\hline & Liquidity (LQ) & $\begin{array}{c}\text { Current assets /current } \\
\text { liabilities }\end{array}$ & + \\
\hline & Solvency (SOL) & $\begin{array}{c}\text { Shareholder equity to total } \\
\text { assets }\end{array}$ & - \\
\hline
\end{tabular}

Source: Own elaboration 
According to Goddard et al. (2004), firm growth and profitability are not essentially associated with each other. Teng and Arslan (2012) found that there is no significant impact of profitability on firm growth. So, the following hypotheses will be created.

$H_{o a}$ : There is a negative relationship between profitability and growth.

$H_{1 a}$ : There is a positive relationship between profitability and growth.

Teng and Arslan (2012) found an insignificant effect of leverage ratio on the growth of the firm. Thus, the following hypotheses can be established:

$H_{o b}$ : There is a positive relationship between leverage and growth.

$H_{1 b}$ : There is a negative relationship between leverage and growth.

According to Cainelli et al. (2006), there is a positive relationship between the ratio of innovation on the growth of a firm. LeBaset al.(2011) found that firms have more growth which innovate than firms that don't. So, the following hypotheses will be created.

$H_{o c}$ : There is a negative relationship between innovation and growth.

$H_{1 c}:$ There is a positive relationship between innovation and growth.

Teng and Arslan (2012) found an insignificant relationship between the ratio of liquidity and growth of the firm. Gill and Mathur (2011) expect that firms with higher liquidity levels will have less strict financing limitations. Anderson (2002) expects that there is a positive relationship between both variables. So, the following hypotheses can be established:

$H_{o d}$ : There is a negative relationship between liquidity and growth.

$H_{1 d}:$ There is a positive relationship between liquidity and growth.

Durinck et al.(1997) found a negative relationship between solvency and firm growth. So, the following hypotheses are created:

$H_{o e}$ : There is a positive relationship between solvency and growth.

$H_{1 e}$ : There is a negative relationship between solvency and growth.

\section{DATA ANALYSIS}

Data analysis is done in the form of descriptive

\section{Table 2: Descriptive Statistics}

\begin{tabular}{|c|c|c|c|c|c|c|}
\hline Variables & variations & Obs & Mean & SD & $\min$ & $\max$ \\
\hline \multirow{3}{*}{ Growth } & overall & 250 & -.0179877 & .8034534 & -5.850742 & .9997792 \\
\hline & between & 50 & & .3472537 & -1.067033 & .3775098 \\
\hline & within & 5 & & .7258714 & -4.801697 & 1.872677 \\
\hline \multirow{3}{*}{ Profitability } & overall & 250 & .1813917 & .4349217 & -3.3818 & 2.175652 \\
\hline & between & 50 & & .2570046 & -.6717063 & 1.482456 \\
\hline & within & 5 & & .3523728 & -2.528702 & 2.218546 \\
\hline \multirow{3}{*}{ Leverage } & overall & 250 & .3232813 & .4092777 & 0 & 2.528104 \\
\hline & between & 50 & & .3913289 & $-2.34 \mathrm{e}-06$ & 2.349015 \\
\hline & within & 5 & & .1297305 & -.2496449 & .990216 \\
\hline \multirow{3}{*}{ Innovation } & overall & 250 & .0879929 & .1858521 & 0 & .6851712 \\
\hline & between & 50 & & .1633092 & $-2.27 e-06$ & .6685725 \\
\hline & within & 5 & & .0911018 & -.2539855 & .5822923 \\
\hline \multirow{3}{*}{ Liquidity } & overall & 250 & 1.469718 & 1.083538 & 0 & 7.05442 \\
\hline & between & 50 & & .9833196 & .0057945 & 4.56822 \\
\hline & within & 5 & & .4718785 & -1.260215 & 3.955918 \\
\hline \multirow{3}{*}{ Solvency } & overall & 250 & .3287823 & .6027356 & -2.079158 & 5.589546 \\
\hline & between & 50 & & .4916882 & -1.934627 & 1.689248 \\
\hline & within & 5 & & .3541419 & -1.317668 & 4.22908 \\
\hline
\end{tabular}

Source: Own elaboration 
statistics, correlation analysis and regression analysis. STATA 11 software is used for the data analysis with panel type of data.

\section{Descriptive STAtistics}

The summary statistics of dependent and independent variables considered in this study (firm's growth, profitability, leverage, innovation liquidity and solvency) are shown in Table II below.

Descriptive statistics as shown above indicate the summary for the current study for growth determinants in the food and textile sectors of Pakistan for the duration of 2013 to 2017. According to the table, 14 firms were analyzed in the current study. Total number of observations in the current study are 250. As per the descriptive analysis table, the contribution of profitability in the current study is almost $18 \%$ as the average in the food and textile sectors of Pakistan while its standard deviation is $43 \%$. The table shows that leverage contributes $32 \%$ on average in this study and the standard deviation shows $40 \%$ variation. The other factors would be examined with the same pattern of evaluation.

\section{Correlation analysis}

Correlation analysis shows the relationship between variables and their coefficients values. The correlation table indicates the correlation matrix between growth and its independent variables of the food and textile sectors of Pakistan over the period 2013 to 2017.

The above table indicates profitability has a positive relationship with a firm's growth and shows its coefficient value of 0.0351 . The other leverage with coefficient value -0.1505 , innovation -0.0831 , liquidity -0.0389 and solvency -0.0254 shows the negative relationship with firm growth which indicates that these factors decrease the firm's growth in the food and textile sectors of
Pakistan for the period 2013 to 2017. Table III also shows the relationship of profitability and firm growth which is positive with the coefficient value 0.0351 .It means the profitability increases the growth of firms in the food and textile sectors of Pakistan for the period 2013-2017.

\section{REGRESSION ANALYSIS}

Table IV given below is showing the results of regression analysis for the study determinants of growth in the food and textile sectors of Pakistan for the period 2013 to 2017.The model selected for this study is the fixed effect regression model.

\section{FINDINGS AND DISCUSSIONS}

The regression findings as given in the above table shows the fixed effect regression model analysis for the study of determinants of growth in the food and textile sectors of Pakistan for the period 2013-2017. The targeted population includes 16 firms of the food sector and 152 firms of the textile sector, but the final sample is 14 and 36 firms from food and textile sectors respectively. The remaining firms are not included in the sample as those firms could not provide the data for the period of study. The overall model is fit and significant in the food and textile sectors of Pakistan. R squared within, between and overall are $76 \%, 38 \% \& 24 \%$ respectively. The reason for the low overall R-square is that only two factors are explaining the variation for the dependent variables while other factors were not explaining it. The significance of the Hausman test (Prob>chi2=0.0337) confirmed the estimation of this study using the fixed effect model. The findings for the relationship between each independent variable and growth of the firm are given under separate headings as follows:

Table 3: Correlation Matrix for Variables

\begin{tabular}{|c|c|c|c|c|c|c|}
\hline & Growth & Profitability & Leverage & Innovation & Liquidity & Solvency \\
\hline Growth & 1.0000 & & & & & \\
\hline Profitability & 0.0351 & 1.0000 & & & & \\
\hline Leverage & -0.1505 & -0.0236 & 1.0000 & & & \\
\hline Innovation & -0.0831 & 0.0196 & 0.2216 & 1.0000 & & \\
\hline Liquidity & -0.0389 & -0.0244 & 0.0476 & 0.2772 & 1.0000 & \\
\hline Solvency & -0.0254 & 0.0846 & -0.0305 & 0.0760 & 0.1987 & 1.0000 \\
\hline
\end{tabular}

Source: Own elaboration 
Table 4: Regression results: (Fixed Effect Regression Model)

\begin{tabular}{|c|c|c|c|c|}
\hline \multicolumn{5}{|c|}{ Dependent variable: firm growth } \\
\hline Independent variables & Coefficients & $t$ values & $P$ values & Std Error \\
\hline Profitability & .1143323 & 0.79 & $0.001^{*}$ & .1452309 \\
\hline Leverage & -1.494604 & -3.82 & $0.000^{*}$ & .391551 \\
\hline Innovation & -.3354551 & -0.58 & 0.560 & .5740052 \\
\hline Liquidity & -.0761753 & -0.69 & 0.489 & .1099894 \\
\hline Solvency & .0674409 & 0.47 & 0.639 & .1437221 \\
\hline Constant & .5637512 & 2.70 & $0.008^{*}$ & .2089891 \\
\hline Targeted population & \multicolumn{4}{|c|}{168 firms (16 Food sector +152 Textile Sector) } \\
\hline Time period & \multicolumn{4}{|c|}{2013 to 2017} \\
\hline Sample size & \multicolumn{4}{|c|}{50 firms (14 Food sector +36 Textile sector) } \\
\hline Total observations & \multicolumn{4}{|c|}{250} \\
\hline Overall model fitness & \multicolumn{4}{|c|}{$\begin{array}{c}F(5,195)=3.22 \\
\text { Prob }>F=0.0081\end{array}$} \\
\hline R-square within & \multicolumn{4}{|c|}{.763} \\
\hline R-square between & \multicolumn{4}{|c|}{.380} \\
\hline R-square overall & \multicolumn{4}{|c|}{.246} \\
\hline Hausman Test & \multicolumn{4}{|c|}{ Prob $>$ chi2 $=0.0337$} \\
\hline Source & \multicolumn{4}{|c|}{ Output from Stata 11} \\
\hline
\end{tabular}

Source: Own elaboration

\section{Ratio of Profitability}

The regression table shows a positive relationship for the ratio of profitability and growth of the firm. The value for the coefficient is .1143323 with P-value as0.001 which is significant at $1 \%$ level. The ratio of profitability if increased by one-unit will increase the growth of the firm by .1143323. Teng and Arslan (2012) found a significant relationship between both variables.

\section{RATIO OF LEVERAGE}

The regression table shows a negative relationship for the ratio of leverage and growth of the firm. The value for the coefficient for this relationship between both variables is -1.494604 with $\mathrm{P}$-value as 0.000 showing the significance at one percent level. It indicates that by increasing one-unit in the ratio of leverage, the growth of the firm will decrease by 1.494604 This result is consistent with the study by Teng and Arslan (2012).

\section{RATIO OF INNOVATION}

The finding of the regression table indicates a negative relationship for the ratio of innovation and growth of the firm. So, the null hypothesis will be accepted, and the alternative will be rejected. The value for the coefficient is -.3354551 which is insignificant at all levels. By increasing one-unit in the ratio of innovation, the growth of the firm may decrease by .3354551 .

\section{RATIO OF LIQUIDITY}

The table shows the negative relationship between liquidity and growth which indicates that one-unit increase in liquidity will decrease the growth by its coefficient value. The findings are similar to Teng and Arslan (2012). They found an in significant relationship between the ratio of liquidity and growth of the firm. The null hypothesis is accepted for this situation.

\section{Ratio OF SOLVENCY}

Table IV shows the negative relationship between solvency and growth. In the case of solvency, the alternative hypothesis will be accepted, and the null will be rejected. These findings are similar to Durinck et al. (1997) who found that the ratio of solvency decreases the growth of the firms. 


\section{Findings FOR EXPECTATIONS AND OBSERVATIONS}

The table below indicates the signs of expectations and signs of observations for comparison in the current study to show the relationship of growth of firms in the textile as well as in the food sector of Pakistan with independent variables like ratio of profitability, ratio of leverage, ratio of innovation, ratio of liquidity and ratio of solvency.

\section{STUDY CONCLUSION}

\section{Summarized Conclusion}

The current research study was conducted to empirically find the determining factors of growth in the textile and food sector of Pakistan. The dependent variable for the current study was the growth of the firms in both sectors while the factors like ratio of profitability, ratio of leverage, ratio of innovation, ratio of liquidity and ratio of solvency being the independent variables were analyzed to verify their effect on growth of the firms in both sectors. For the purpose of analysis, financial statements of listed companies from the textile and food sectors were utilized for data collection purposes for the variables of the study. The nature of the collected data was a balanced panel and for analysis' purpose, fixed effect estimation technique was used after confirming the significance of the (Housman, 1970) specification test. In addition, the panel descriptive statistics, as well as Pearson correlation, were also reported in the data analysis of the current study. The findings of the study indicate that the ratio of leverage have a significant and negative effect while the ratio of innovation, ratio of liquidity and ratio of solvency have negative and insignificant effect on the growth of firms in both sectors. Profitability has positive and significant effect on growth of the firms.

\section{IMPLICATION OF THE STUDY}

Policymakers in both sectors, textile as well as in the food sector of Pakistan, should take into consideration the factors affecting the growth of the firm. They should take utmost care while taking decisions about the growth of the firms in both sectors so that a careful decision for enhancing growth in both sectors can be made.

\section{LIMITATIONS AND SUGgESTIONS FOR FUTURE RESEARCG}

The current study suffers some limitations; first, the study is only applicable to the non-financial sector of Pakistan, because of different financial structures and operations. Second, limited data for the period 2013 to 2017 is used for analysis. A study with data over a longer period of time would conclude more accurate results. Third, limited numbers of factors are used to measure firm growth, but future researchers may use some specific factors that would help them to get more accurate results.

Table 5: Signs for Expectations and Observations

\begin{tabular}{|c|c|c|c|c|}
\hline Sr\# & $\begin{array}{c}\text { Independent } \\
\text { variables }\end{array}$ & $\begin{array}{c}\text { Signs of } \\
\text { Expectations }\end{array}$ & $\begin{array}{c}\text { Signs of } \\
\text { Observations }\end{array}$ & $\begin{array}{c}\text { Acceptance/ } \\
\text { Rejection of Hificance/ Not } \\
\text { Significance }\end{array}$ \\
\hline $\mathbf{1}$ & Profitability & $(+/-)$ & + & Rejected \\
\hline $\mathbf{2}$ & Leverage & $(+/-)$ & - & Rejected \\
\hline $\mathbf{3}$ & Innovation & $(+/-)$ & - & Accepted \\
\hline $\mathbf{4}$ & Liquidity & $(+/-)$ & - & Accepted \\
\hline $\mathbf{5}$ & Solvency & $(+/-)$ & Rejected & NS \\
\hline
\end{tabular}

Source: Own elaboration 


\section{REFERENCES}

Anderson, R.W. (2002). Capital Structure, Firm Liquidity and Growth. NBB Working Paper, 27.

Becchetti, L. (2001). The Determinants of Growth for Small and Medium-Sized Firms.The Role of the Availability of External Finance. Small Business Economics, 305.

Cainelli, G., Evangelista, R., Savona, M. (2005). Innovation and Economic Performance in Services: a Firm-level Analysis. Cambridge Journal of Economics, 30(3), 435-458.

Davidsson, Per. (2010). Small Firm Growth. Foundations and Trends ${ }^{\circledR}$ in Entrepreneurship 6(2), 69-166. 10.1561/0300000029.

Durinck, E., Laverne, E., Lybaert, N. (1997). The Impact of Sales Growth above a Sustainable Level on the Financing Choice of Belgian Industrial SME's. Working Paper, UFSIA, Antwerpen.

Glancey, K. (1998). Determinants of Growth and Profitability in Small Entrepreneurial Firms.International Journal of Entrepreneurial Behaviour\& Research, 4(1), 18-27.

Goddard, J., Molyneux, P., Wilson, J. (2004). Dynamics of Growth and Profitability in Banking. Journal of Money, Credit \& Banking, 36, 1069-1091.

Gibrat, R. (1931). Les Inégalités Économiques, Librairie du Recueil Sirey, Paris.

Gill, A., Mathur, N. (2011). Factors that Affect the Potential Growth of Canadian Firms. Journal of Applied Finance and Banking, 1(4), 107.

Honjo, Y., Harada, N. (2006). SME Policy, Financial Structure and Firm Growth: Evidence from Japan. Small Business Economics, 27(4-5), 289-300.

Khan, T.H. (2012). Determinants of Firm Growth: Evidence from Belgian Companies. Universiteit Gent, 30.

Lewis, V.L., Churchill, N.C. (1983). The Five Stages of Small Business Growth. Harvard Business Review, 61(3), 30-50. Retrieved from SSRN: https://ssrn.com/abstract=1504517.

Le Bas, C., Haned, N., Colombelli, A. (2011). On Firm Growth and Innovation - Some New Empirical Perspectives Using French CIS, 1992-2004, ICER Working Paper, No. 7/2011.

Loi, T.H., Khan, A.A. (2012). Determinants of Firm Growth: Evidence from Belgian Companies. Master thesis. University of Gent.

Oh, D.H., (2010). A Meta-frontier Approach for Measuring an Environmentally Sensitive Productivity Growth Index. Energy Economics, 32, 146-157.

Panda, D. (2015). Growth Determinants in Small Firms. International Journal of Commerce and Management, 25(1, 5266. DOI: 10.1108/IJCOMA-12-2012-0080.

Pattitoni, P., Petracci, B., Spisni, M. (2014). Determinants of Profitability in the EU-15 Area Determinants of Profitability in the EU-15 Area. Applied Financial Economics, 24(11), 763-775. Https://doi.org/10.1080/09603107.2014.904488.

Pedro Guedes de Carvalho, P.M. (2013). Growth Determinants of Small- and Medium-sized. European Sport Management Quarterly, 13(4), 428-449.

Rehman, N.U. (2015). Drivers of Firms' Growth: a Case Study of Software Firms in Islamabad/Rawalpindi. Journal of Management Development, 34(8), 901-921. https://doi.org/10.1108/JMD-05-2014-0041

Sievers, T.S. (2013). Determinants of Market Beta: the Impacts of Firm-specific. Springer, 570.

Schlueter, T., Sievers, S. (2014). Determinants of Market Beta: the Impacts of Firm-specific Accounting Figures and Market Conditions. Review of Quantitative Finance and Accounting, 42, 535-570. Https://doi.org/10.1007/s11156-0130352-1.

Vassolo, R.S., Hermelo, F.D. (2007). The Determinants of a Firm's Growth: an Empirical Examination. Revista Abante, 10(1), 3-20. 